\title{
PERTANGGUNGJAWABAN PIDANA TERHADAP PENGGUNA IJAZAH PALSU OLEH ANGGOTA DPRD DALAM PEMILIHAN UMUM LEGISLATIF (CONTOH KASUS PUTUSAN NOMOR: 196 K/PID.SUS/2016)
}

\author{
Hery Firmansyah \\ (Dosen Fakultas Hukum Universitas Tarumanagara. Meraih Sarjana Hukum pada Fakultas Hukum \\ Universitas Gadjah Mada, Magister Hukum Bisnis pada Fakultas Hukum Universitas Gadjah Mada, \\ Magister Administrasi Publik pada Fakultas Hukum Universitas Gadjah Mada Yogyakarta.) \\ (E-mail: heryf@fh.untar.ac.id) \\ Imelda Yohana Dewi \\ (Mahasiswa Program S1 Fakultas Hukum Universitas Tarumanagara)
}

Received: 22 April 2019; Accepted: 29 Mei 2019; Published: 10 Juni 2019

\begin{abstract}
A diploma is usually used as one of the conditions to meet the requirements for registration or recruitment from a position. For example, for the nomination of legislative members to be members of the DPR, DPD, Provincial DPRD and Regency DPRD. However, most legislative candidates in the regions do not have genuine diplomas for certain reasons, eventually the legislative candidates use fake diplomas in order to qualify in the general election. The problem studied is how criminal accountability of fake diploma users by DPRD members in legislative elections (Case Example Decision Number: $196 \mathrm{~K} /$ Pid.Sus / 2016)? The research method that I use is a normative legal research method which is also supported by interview data. The author analyzes that criminal liability is adjusted to the condition that a person can be held accountable based on criminal acts committed and articles used where the sanctions are there, in this case the article imposed is Article 69 paragraph (1) of the Law on the National Education System. When viewed from a decision that is used as an example by referring to its legal considerations, a court judge has considered everything so that he can be held to hold criminal responsibility and the judge has the right to decide. The author advises to conduct socialization so that there is no indication of the use of fake diplomas, it is necessary to impose a severe sentence for each actor, and the legislative candidates to be honest in nominating themselves as representatives of the people.
\end{abstract}

Keywords:Criminal Liability, Foregery Diploma

\section{PENDAHULUAN}

\section{A. Latar Belakang}

Indonesia adalah negara hukum hal ini ditegaskan dalam Pasal 1 ayat (3) Undang-Undang Dasar Negara 
Republik Indonesia Tahun 1945 bahwa

Negara Republik Indonesia berdasarkan atas hukum. Hukum dikatakan sebagai sesuatu yang paling tinggi (supreme) yang mana merupakan cita-cita umat manusia di seluruh dunia yang mendambakan ketenangan, ketentraman, dan kesejahteraan. ${ }^{1}$ Dengan demikian, salah satu definisi dari hukum adalah sebagai rangkaian peraturan-peraturan mengenai tingkah laku orang-orang sebagai anggota masyarakat, sedangkan satu-satunya tujuan dari hukum ialah mengadakan keselamatan, kebahagiaan, dan tata tertib di dalam masyarakat. ${ }^{2}$

Hukum memiliki peran yang sangat penting yang dipakai untuk melaksanakan ketertiban masyarakat. Maka dari itu, hukum dikodifikasikan dan terbentuklah Kitab Undang-Undang Hukum Pidana, Kitab Undang-Undang Hukum Acara Pidana, Kitab UndangUndang Hukum Perdata, Kitab Undang-

1) Viswandro, dan Maria Matilda, dan Bayu Saputra, Mengenal Profesi Penegak Hukum, Cetakan ke-1, (Yogyakarta: penerbit Medpress Digital, 2015), 1.

2) Wirjono Prodjodikoro, Asas-Asas Hukum Pidana di Indonesia, Edisi kedua, (Bandung: Eresco, 1986), 14.
Undang Hukum Acara Perdata, Kitab Undang-Undang Hukum Dagang dan peraturan-peraturan lainnya yang isinya berupa perintah, larangan serta sanksisanksinya. Hukum mempunyai sanksi atau akibat hukum sehingga pemberlakuannya dapat dipaksakan atau bersifat memaksa. Sehubungan dengan karakteristiknya bahwa ada sanksi dalam hukum, maka dikenal dengan istilah lex perfecta. lex perfecta yaitu peraturan-peraturan yang diikuti dengan sanksi (akibat hukum). Dalam lex perfecta, peraturan melarang atau sebaliknya mengharuskan dilakukannya suatu perbuatan, di mana larangan atau keharusan berbuat ini disertai dengan ketentuan tentang sanksi (akibat hukum) jika dilanggar. ${ }^{3)}$

Sanksi atau hukuman adalah akibat dari penerapan hukum tadi yang maknanya lebih luas daripada pengertian pidana, sebab mencakup juga keputusan hakim dalam lapangan hukum perdata. ${ }^{4}$ ) Seseorang yang melanggar hukum dapat dikenakan

${ }^{3)}$ Ibid., 18.

4) Muladi, Barda Nawawi, Teori-Teori dan Kebijakan Pidana, Cetakan ke-2, (Bandung: Penerbit Alumni, 1992), 1. 
pidana karena telah melakukan tindak pidana. Tindak pidana merupakan tindakan melanggar hukum yang telah dilakukan dengan sengaja ataupun tidak dengan sengaja oleh seseorang yang dapat dipertanggungjawabkan atas tindakannya dan yang oleh undangundang telah dinyatakan sebagai suatu tindakan yang dapat dihukum. ${ }^{5}$ ) Perbuatan-perbuatan pidana menurut sistem Kitab Undang-Undang Hukum Pidana dibagi atas kejahatan (misdrijven) dan pelanggaran (overtredingen).

Kejahatan sekarang ini sering terjadi dimana saja, salah satu bentuk kejahatan yang paling banyak terjadi di masyarakat adalah mengenai pemalsuan. Kejahatan pemalsuan adalah berupa kejahatan yang di dalamnya mengandung unsur keadaan ketidakbenaran atau palsu atas sesuatu (objek), yang sesuatunya itu tampak dari luar seolah-olah benar adanya padahal sesungguhnya bertentangan dengan yang sebenarnya. Kejahatan pemalsuan yang dimuat dalam Buku II

5) Lamintang, Dasar-Dasar Hukum Pidana Indonesia, (Bandung: Sinar Baru, 1984), 176.
KUHP dikelompokkan menjadi 4 golongan, yakni: ${ }^{6}$

1. Kejahatan sumpah palsu (Bab IX)

2. Kejahatan pemalsuan uang (Bab X)

3. Kejahatan pemalsuan materai \& merek (Bab $\mathrm{XI})$

4. Kejahatan pemalsuan surat (Bab XII)

Dari pengelompokan terhadap beberapa kejahatan di atas, kejahatan pemalsuan surat masih banyak menjamur di kalangan masyarakat. Pengaturan mengenai pemalsuan surat ini diatur mulai dari Pasal 263 Kitab Undang-Undang Hukum Pidana sampai dengan Pasal 276 Kitab UndangUndang Hukum Pidana. Pemalsuan surat dalam Pasal 263 Kitab UndangUndang Hukum Pidana terdiri dari dua bentuk tindak pidana, masing-masing dirumuskan dalam ayat (1) dan ayat (2). Berdasarkan unsur perbuatannya pemalsuan surat ayat (1), disebut

6) Adami Chazawi, Kejahatan Mengenai Pemalsuan, (Jakarta: PT Raja Grafindo Persada, 2002), 2-3. 
dengan membuat surat palsu dan memalsu surat, sementara pemalsuan surat dalam ayat (2) disebut dengan memakai surat palsu atau surat yang palsu. ${ }^{7)}$ Meskipun kedua ayat ini saling berhubungan satu dengan yang lainnya namun, kedudukan keduanya berdiri sendiri-sendiri, dimana berbeda tempat dan waktu tindak pidananya serta dapat dilakukan oleh si pembuat yang tidak sama. ${ }^{8)}$

Salah satu bentuk kejahatan pemalsuan surat ini adalah pemalsuan ijazah. Ijazah merupakan sertifikat atau dokumen penting milik seseorang yang diberikan kepadanya karena telah selesai menempuh jenjang pendidikan yang mana diterbitkan oleh pihak yang berwenang yaitu Departemen Dinas Pendidikan melalui jalur pendidikan yang tercantum dalam undang-undang.

Pentingnya ijazah bagi masyarakat membuat orang-orang banyak melakukan berbagai cara agar mendapatkan ijazah tersebut, apalagi ketika orang tersebut dinyatakan tidak lulus ujian atau memang tidak

\footnotetext{
7) Ibid., 137.

${ }^{8)}$ Ibid., 137.
}

mengikuti program pendidikan Sekolah Dasar (SD), Sekolah Menengah Pertama (SMP), Sekolah Menengah Atas (SMA), atau Perguruan Tinggi. Maka, peluang untuk mendapatkan ijazah tersebut sangat kecil atau bahkan tidak mungkin, untuk itu banyak dari mereka akhirnya melakukan perbuatan memalsukan ijazah mulai dari membuat, membeli sampai menggunakan ijazah palsu. Ijazah dapat dikatakan palsu sebetulnya bisa dilihat dari bentuk dan ciri-ciri atau isi ijazah itu sah atau tidak. Kriteria atau ukurannya yaitu: ${ }^{9)}$

1. Blanko ijazah adalah palsu.

2. Blanko itu sah, dan dikeluarkan oleh lembaga pendidikan yang berwenang tapi ditanda tangani oleh pejabat yang tidak berwenang.

3. Blanko itu sah, dan dikeluarkan oleh lembaga pendidikan yang diakui serta ditanda tangani oleh pejabat

\footnotetext{
9) Angel Michelle Karinda, "Kajian Yuridis Terhadap Tentang Pemalsuan Pemalsuan Ijazah Menurut Pasal 263 dan 264 KUHP”, Lex Crimen Vol. V Tahun 2016, 141.
} 
yang berwenang tapi isinya sebagian atau seluruhnya adalah palsu.

Penggunaan ijazah biasanya dipakai sebagai salah satu syarat untuk memenuhi persyaratan pendaftaran diri dari suatu jabatan. Contohnya dipakai untuk pencalonan sebagai anggota legislatif. Tindakan menggunakan ijazah palsu pengaturannya secara khusus tertulis dalam Pasal 69 ayat (1) dan ayat (2) Undang-Undang Nomor 20 Tahun 2003 tentang Sistem Pendidikan Nasional. Dalam Pasal 51 ayat (2) UndangUndang No. 8 Tahun 2012 tentang Pemilihan Umum Anggota Legislatif untuk periode 2014-2019, dicantumkan bahwa calon anggota legislatif harus memenuhi syarat kelengkapan administrasi yang salah satu syaratnya harus menyertakan bukti kelulusan pendidikan terakhir berupa fotokopi ijazah, surat tanda tamat belajar (STTB), dan lain-lain yang dilegalisasi oleh satuan pedidikan atau program pendidikan menengah. Namun, dikarenakan persyaratan tersebut merupakan suatu keharusan, kebanyakan para calon anggota legislatif di daerah yang tidak memiliki ijazah asli karena alasan tertentu akhirnya menggunakan ijazah palsu ini agar supaya lolos menjadi calon anggota anggota legilsatif. Sudah banyak kasus tentang calon anggota legislatif daerah yang menggunakan ijazah palsu dalam pencalonannya dalam pemilihan umum legislatif mulai dari periode 2009-2014, periode 2014-2019, bahkan untuk periode 2019-2024 masih diselidiki banyak calon anggota legislatif yang menggunakan ijazah palsu. Kasus yang penulis angkat adalah sebagaimana dalam contoh kasus penggunaan ijazah palsu dalam putusan nomor: 196 K/Pid.Sus/2016 yang terjadi dalam wilayah pencalonan anggota Dewan Perwakilan Rakyat Daerah kabupaten yang ada di Lubuk Linggau, Sumatera Selatan untuk periode 2014-2019, Edi Sukamto, SE Bin H. Japarin (terdakwa). 
Bermula pada saat penyelenggaraan pemilihan umum calon legislatif, pada bulan April 2013, Partai Hanura Kabupaten. Musi Rawas mengajukan terdakwa menjadi Daftar Calon Sementara (DCS), hingga pada bulan Mei 2013 Partai Hanura Kabupaten. Musi Rawas mengajukan terdakwa ke Komisi Pemilihan Umum (KPU) setempat untuk menjadi Daftar Calon Tetap (DCT), selanjutnya mengisi formulir pendaftaran bakal calon anggota legislatif serta melengkapi data-data administrasi seperti menyertakan fotokopi ijazah yang dilegalisir lalu diserahkan ke KPU setempat. Pada saat pemilihan umum legislatif berlangsung, terdakwa terpilih menjadi anggota Dewan Perwakilan Rakyat Daerah daerah pemilihan 5 (lima) Kabupaten Muratara (perluasan Kabupaten Musi Rawas) untuk periode 2014-2019 karena memperoleh suara terbanyak kedua.

Pada tanggal 20 November 2013 ternyata ada laporan yang mana disampaikan ke Lembaga
Swadaya Masyarakat (LSM) yang menyatakan ada anggota Dewan Perwakilan Rakyat Daerah menggunakan ijazah palsu pada saat mencalonkan diri, lalu di bulan Desember 2013 saksi Malhendra (anggota Dewan Perwakilan Rakyat Daerah Kabupaten Muratara sekaligus anggota LSM) mengecek dan mencari informasi ke Komisi Pemilihan Umum Kabupaten. Muratara dan mendapatkan fotokopi ijazah terdakwa yang mana pihak yang mengeluarkan ijazah adalah Dinas Pendidikan Kota Depok. Selanjutnya, diadakannyalah pemeriksaan atas ijazah tersebut dan terbukti ternyata terdakwa menggunakan ijazah palsu. Terdakwa akhirnya dikenakan Pasal 69 ayat (1) Undang-Undang Nomor 20 Tahun 2003 tentang Sistem Pendidikan Nasional karena melanggar salah satu syarat administratif sebagai calon anggota legislatif yang tercantum dalam Pasal 51 ayat (2) Undang-Undang Nomor 8 Tahun 2012 tentang Pemilihan Umum 
Anggota DPR, DPD dan DPRD

terkait menggunakan ijazah palsu.

Berdasarkan uraian tersebut di atas, maka dalam penulisan skripsi ini penulis tertarik untuk mengangkat judul:

"PERTANGGUNG

JAWABAN

PIDANA

TERHADAP

PENGGUNA

IJAZAH PALSU OLEH

ANGGOTA DPRD DALAM

PEMILIHAN

UMUM

LEGISLATIF (CONTOH

KASUS PUTUSAN NOMOR: 196 K/PID.SUS/2016)".

\section{B. Perumusan Masalah}

Berdasarkan uraian di atas maka permasalahan yang hendak penulis rumuskan adalah Bagaimana pertanggungjawaban pidana terhadap pengguna ijazah palsu oleh anggota Dewan Perwakilan Rakyat Daerah dalam pemilihan umum legislatif (contoh kasus putusan nomor: 196 K/Pid.Sus/2016.

\section{PEMBAHASAN}

A. Pertanggungjawaban Pidana Terhadap Pengguna Ijazah Palsu
Oleh Anggota DPRD Dalam Pemilihan Umum (Contoh Kasus

Putusan Nomor:

196

K/Pid.Sus/2016)

Perbuatan pidana mengenai pemalsuan ijazah dikategorikan sebagai perbuatan pidana pemalsuan surat yang mana diatur dalam Pasal 263 Kitab UndangUndang Hukum Pidana terutama bagi mereka yang dengan sengaja menggunakan ijazah palsu (surat palsu) pengaturannya ada dalam Pasal 263 ayat (2) Kitab UndangUndang Hukum Pidana yaitu diancam dengan pidana yang sama, barangsiapa dengan sengaja memakai surat palsu atau dipalsukan seolah-olah sejati, jika pemakaian surat itu dapat menimbulkan kerugian. Hal ini berdasarkan asas legalitas, bahwa tiada perbuatan dapat di pidana kecuali di dalam undang-undang telah diatur, karena sudah ada aturannya dan mana perbuatan itu bertentangan dengan hukum atau dengan kata lain telah memenuhi unsur melawan hukum maka si 
pengguna ijazah palsu dapat dijerat dengan Pasal 263 ayat (2) Kitab Undang-Undang Hukum Pidana tersebut. Namun, isi dalam Pasal 263 Kitab Undang-Undang Hukum Pidana ini tidak mengatur secara khusus dan tegas mengenai pemalsuan ijazah dan jika ditelaah terdapat pengaturan khusus mengenai barangsiapa dengan sengaja menggunakan ijazah yang terbukti palsu yaitu ada dalam Pasal 69 ayat (1) Undang-Undang Nomor 20 Tahun 2003 tentang Sistem Pendidikan Nasional, yaitu setiap orang yang menggunakan ijazah, sertifikat kompetensi, gelar akademik, profesi, dan/atau vokasi yang terbukti palsu dipidana dengan pidana penjara paling lama lima tahun dan/atau pidana denda paling banyak Rp 500.000.000,00 (lima ratus juta rupiah).

Sependapat dengan pendapat yang diutarakan oleh Bapak Abdul Ficar, bahwa sistem hukum pidana kita secara umum di dalam Kitab Undang-Undang Hukum
Pidana sudah mengatur mengenai pemalsuan surat yang di dalamnya termasuk pemalsuan surat yang sifatnya otentik dalam hal ini akta otentik termasuk ijazah palsu. Selanjutnya, karena pemalsuan ijazah ini bagian dari dunia pendidikan ada pengaturan khususnya yaitu di dalam undangundang pendidikan nasional, yang diatur dalam Pasal 69 UndangUndang Nomor 20 Tahun 2003 tentang Sistem Pendidikan Nasional.

Ijazah termasuk ke dalam bagian instrumen pendidikan oleh karena itu, undang-undang pendidikan nasional juga mengatur mengenai pidananya sehingga bisa dijerat dengan dua pasal (pasal yang tercantum dalam KUHP maupun pasal yang tercantum dalam Undang-Undang Sistem Pendidikan Nasional). Jadi, kalau yang dipalsukan adalah ijazah sekolah maka lebih tepat yang dijatuhkan adalah pasal dalam Undang-Undang Sistem Pendidikan Nasional. Memang 
secara umum telah diatur dalam KUHP namun misalnya penggunaan ijazah palsu tidak diatur dalam Undang-Undang Sistem Pendidikan Nasional oleh KUHP dengan istilah surat/akta otentik sudah terakomodir. ${ }^{10}$ ) Begitupula dengan pandangan dari Ibu Hakim Tuty Haryati bahwa pemalsuan sudah diatur dalam KUHP dan beliau baru mengetahui ada undang-undang lain yang mengatur mengenai penggunaan ijazah palsu ini.

Kerap kali jaksa dalam dakwaannya terhadap terdakwa yang menggunakan ijazah palsu dituntut dengan pasal yang ada di KUHP, sehingga hakim dalam putusannya pun menjatuhkan pidana berdasarkan pasal yang ada dalam KUHP tersebut, padahal sudah ada secara khusus diatur bagi mereka yang dengan sengaja menggunakan ijazah yang terbukti palsu. Terkait

\footnotetext{
${ }^{10)}$ Peneliti, Wawancara, dengan Bapak Abdul Ficar Dosen Universitas Trisakti (Jakarta: Universitas Trisakti, 26 April 2019).
}

penggunaan ijazah palsu, Pasal 69 ayat (1) Undang-Undang Nomor 20 Tahun 2003 Tentang Sistem Pendidikan Nasional sudah mengatur mengenai penjatuhan pidana penjara dan pidana denda. Mengenai penjatuhan pidana memang harus melihat unsurunsur dari pasal yang dijatuhkan kepada si terdakwa karena selain telah memenuhi unsur-unsur yang telah dirumuskan dalam undangundang juga agar supaya menghindari salah menerapkan hukum.

Dalam teori pertanggungjawaban pidana, seseorang yang melakukan perbuatan melawan hukum belum cukup untuk dijatuhi pidana dimana harus ada kemampuan untuk bertanggunggjawab dari dalam diri pelaku yang dapat dimintai pertanggungjawaban, sehingga dalam hal ini harus melihat unsur seseorang yang mampu bertanggungjawab atas perbuatannya, unsur kesalahan di dalamnya baik itu perbuatan yang 
sengaja ataupun lalai dan ada perbuatan yang bertentangan dengan hukum atau harus ada unsur melawan hukum. Seseorang yang dapat dimintai pertanggungjawaban adalah seseorang yang sehat akal dan jiwanya serta dapat menentukan kehendaknya untuk berbuat tindak pidana tersebut.

Unsur kesalahan merupakan unsur penting yang harus ada dalam pertangunggjawaban pidana, karena dalam melakukan perbuatan pidana ada kehendak atau niat dalam diri si pelaku untuk melakukan perbuatan tersebut. Sehingga ada hubungan batin antara si pelaku dengan perbuatan yang dilakukannya. Kesalahan pun memiliki kaitan dengan pertanggungjawaban karena dalam diri si pembuat harus ada kemampuan untuk dimintai pertanggungjawaban.

Ada aliran dalam teori pertanggungjawaban pidana, dimana aliran dualistis pahamnya memberikan rasa keadilan bagi orang yang melakukan perbuatan pidana namun tidak bisa dimintai pertanggungjawaban. Karena, ada aliran yaitu aliran monistis yang menganut paham bahwa seseorang yang melakukan tindak pidana dengan otomatis juga harus bertanggungjawab atas perbuatannya, paham itu menyatukan unsur perbuatan melawan hukum dengan penjatuhan pidana. Hal ini penulis nilai tidak mencerminkan rasa keadilan, seandainya orang yang melakukan perbuatan pidana ternyata adalah orang itu disuruh? Ini menjadi sebuah pertanyaan karena yang akan bertanggungjawab adalah dia yang melakukan perbuatan pidana, padahal kenyataannya orang tersebut disuruh untuk melakukan perbuatan pidana atau contoh lain seorang anak kecil yang melempar batu kepada seseorang yang sedang berjalan. Dalam kasus ini anak kecil tersebut melakukan perbuatan pidana, dan belum bisa 
menginsyafi perbuatannya yang akan menimbulkan akibat bagi yang dillempar batu tersebut maka anak kecil tersebut tidak bisa dimintai pertanggungjawaban.

Namun, dijaman yang modern ini paham mengenai yang melakukan perbuatan pidana harus bertanggungjawab dengan dijatuhi pidana, penulis lihat sudah dikesampingkan dan dengan kata lain sudah tidak ada yang menganut paham tersebut, karena sekarang ada pemisahaan mengenai siapa yang harus bertanggungjawab atas perbuatan pidana dan harus memenuhi syarat-syarat kemampuan untuk bertanggungjawab, karena pelaku tindak pidana bukan hanya dia yang melakukan namun ada juga penyertaan (pelaku yang menyuruh melakukan, yang turut serta melakukan dan penganjur) sebagaimana yang mana tercantum dalam Pasal 55 Kitab Undang-Undang Hukum Pidana dan pembantu sesuatu kejahatan
56 Kitab Undang-Undang Hukum Pidana.

Dari sini akan terlihat apakah telah memenuhi unsur kemampuan bertanggungjawab agar pelaku kejahatan dapat dimintai pertanggungjawaban. Karena orang yang mampu bertanggungjawab

(toerekeningsvat barheid), keadaan jiwa seseorang harus sedemikian rupa, sehingga ia harus dapat menginsyafi bahwa perbuatan yang dilakukan itu adalah perbuatan yang terlarang, dan orang itu harus dapat menentukan kehendaknya terhadap perbuatannya. Jadi, seseorang dapat dimintai pertanggungjawaban pidana dengan melihat keadaan jiwanya yang sehat dan adanya kehendak untuk melakukan perbuatan pidana tersebut, yang mana sebelumnya telah melakukan perbuatan, yang perbuatannya tersebut bertentangan dengan hukum atau di dalamnya 
terkandung unsur melawan hukum.

Jika dijabarkan bahwa unsur pertanggungjawaban pidana untuk dapat dipidananya si pembuat yang harus dipenuhi adalah adanya tindak pidana yang dilakukan oleh pelaku, adanya unsur kesalahan berupa kesengajaan atau kealpaan, adanya pelaku yang mampu bertanggungjawab dan tidak ada alasan pemaaf bagi si pelaku. Pertanggungjawaban pidana hanya dapat terjadi jika sebelumnya sudah ada tindak pidana yang dilakukan, jadi tidak sekaligus apabila seseorang telah melakukan tindak pidana orang tersebut langsung dijatuhi pidana karena dianggap mampu bertanggungjawab.

Pertanggungjawaban pidana sesuai dengan apa yang dikemukakan oleh Bapak Abdul Ficar, Dosen Universitas Trisakti, pelaku dihukum atau dijatuhi pidana karena ada 4 hal: ${ }^{11)}$

a. Perbuatan pidana yang dilarang (actus reus)

b. Ada kesalahannya atau (mens rea) : kesalahan akan terlihat dari apakah dia melakukan perbuatan itu sengaja (dollus) atau kealpaan/tidak sengaja (culpa).

c. Dapat dipertanggungjawabkan.

Contoh: Kalau anak kecil dibawah 10 tahun nembak ibunya sampai mati, tidak bisa dihukum karena adanya alasan pemaaf makanya dia tidak bisa dihukum. Ada anak yang berhadapan dengan hukum berumur 14 tahun keatas dia bisa ditahan, kalau dibawah 14 tahun ada proses atau pemberlakuan yang lain. Anakanak dibawah 14 tahun, orang gila tidak bisa dimintai pertanggungjawaban, diluar daripada itu bisa dimintai pertanggungjawaban.

Tidak ada alasan pemaaf (Pasal 48, Pasal 49, Pasal 50, Pasal 51 Kitab Undang-Undang Hukum Pidana).

11) Ibid., 
Mengenai pertanggungjawaban pidana adanya di poin $b, c$, dan $d$. maksud pertanggungjawaban pidana adalah perbuatan pidananya sudah ada, selanjutnya apakah dia bisa dihukum apa tidak, jikalau perbuatan tersebut merupakan sebuah kealpaan bukan dia yang membuat hal tersebut bisa dijadikan alasan pemaaf.

Menurut hakim Pengadilan Negeri Jakarta Pusat, Tuty Haryati bahwa pertanggungjawaban pidana bagi mereka yang melakukan tindak pidana, pertanggungjawaban pidana disesuaikan dengan pasal yang ada di KUHP atau undang-undang khusus yang dipakai dimana sanksinya ada disitu, condong atau merujuk ke pasal yang di dakwakan. $^{12)}$

Kasus yang diangkat oleh penulis bahwa ada oknum anggota Dewan Perwakilan Rakyat Daerah Kabupaten Muratara Sumatera Selatan yang menggunakan ijazah

12 ) Peneliti. Wawancara, dengan Hakim Pengadilan Negeri Jakarta Pusat, (Jakarta: Pengadilan Negeri Jakarta Pusat, 11 Juni 2019). palsu pada saat mencalonkan diri sebagai anggota legislatif, pada saat itu oknum ini menggunakan ijazah palsu tersebut ( ijazah paket B dan ijazah paket C) dengan sengaja dan baru diketahui ketika dia sudah menjabat sebagai Anggota Dewan Perwakilan Rakyat Daerah Kabupaten. Muratara.

Dilihat dari kronologi kasusnya bahwa awalnya dia terpilih sebagai calon sementara yang diusung oleh partai politiknya lalu dijadikan daftar calon anggota tetap, lalu Edi Sukamto (oknum anggota Dewan Perwakilan Rakyat Daerah) ini mengisi syarat-syarat administrasi yang salah satunya adalah mengisi daftar riyawat hidup yang di dalamnya berisi riyawat pendidikan dan melampirkan fotokopi ijazah pendidikannya dimana dia melampirkan fotokopi ijazah paket B dan fotokopi ijazah paket C yang dilegalisir yang keduanya dikeluarkan oleh Dinas Pendidikan Kota Depok, ketika ada laporan Edi Sukamto menggunakan ijazah palsu dilakukan klarifikasi dengan 
melakukan perbandingan dengan ijazah lain yang dikeluarkan oleh Dinas Pendidikan Kota Depok, dan ternyata benar ijazah yang dipakai pada saat pencalonannya sebagai anggota Dewan Perwakilan Rakyat Daerah terbukti palsu.

Pada saat dilaporkan dari sudah sampai di persidangan belum ada perlawanan dari oknum anggota DPRD ini, namun karena dia diusung oleh partai politik yang merupakan syarat untuk menjadi anggota Dewan Perwakilan Rakyat Daerah maka beliau dilakukan pemecatan. Namun, oknum ini tidak terima sehingga dia melakukan perlawanan hukum dengan menggugat partai politiknya dan di dalam putusannya oknum anggota Dewan Perwakilan Rakyat Daerah ini kalah, jadi ada dua permasalahan hukum yang berkaitan dengan dirinya, yang pertama mengenai penggunaan ijazah palsu dan yang kedua adalah tidak terimanya oknum anggota Dewan Perwakilan Rakyat Daerah mengenai pemecatan dirinya oleh partai politik yang mengusung dirinya.

Pengguna ijazah palsu tersebut sudah didakwakan dengan dakwaan alternatif yang mana akhirnya hakim menjatuhkan putusannya dengan mendakwa dengan Pasal 69 ayat (1) Undang-Undang Nomor 20 Tahun 2003 Tentang Sistem Pendidikan Nasional dengan pidana penjara 1 tahun dan dengan 100 juta rupiah.

Penulis sependapat dengan kedua pendapat narasumber tersebut, karena sesuai dengan teori bahwa pertanggungjawaban pidana harus memenuhi:

1. Telah dilakukannya tindak pidana Dalam kasus ini bahwa telah terjadi tindak pidana pemalsuan ijazah atau lebih konkritnya dengan sengaja menggunakan ijazah yang terbukti palsu yang digunakan dalam pemilihan umum legilatif di daerah. Jelas unsur ini telah terpenuhi.

2. Adanya kesalahan (dollus atau culpa) 
Dalam kasus ini si pengguna ijazah palsu di dalam putusannya telah memenuhi unsur dengan sengaja menggunakan ijazah yang terbukti palsu, berarti dalam melakukan tindak pidananya dia dengan sengaja menggunakan ijazah palsu agar supaya lolos menjadi anggota legislatif, dan lagi dia membayar orang sebesar Rp. 10.000.000,00 (sepuluh juta rupiah) agar ijazah Paket B dan Paket C berada di tanganya. Sehingga menurut penulis adanya unsur kesalahan dalam kasus ini telah terpenuhi.

3. Kemampuan bertanggungjawab

Dalam kasus ini bahwa si terdakwa adalah orang yang sehat jiwa dan raganya. Jika dilihat dari putusan bahwa si terdakwa ini adalah oknum anggota Dewan Perwakilan Rakyat Daerah yang mana pada saaat pencalonan dirinya sebagai anggota legislatif yang salah satu syaratnya adalah sehat jasmani dan rohani. Oknum ini dengan sengaja menggunakan ijazah palsu dalam pemilihan legislatif pasti menyadari apa akibat yang ditimbulkan dari perbuatan yang dilakukannya. Jika dilihat dari umurnya pun oknum ini merupakan orang yang sehat jadi menurut penulis bisa dimintai pertanggungjawaban.

Dia memiliki kehendak untuk menggunakan ijazah itu dan dia menginsyafi akan akibat dari perbuatannya itu namun selama masih atau belum ada yang memperkarakan oknum ini masih dapat melaksanakan tugasnya sebagai anggota Dewan Perwakilan Rakyat Daerah. Jika dilihat apakah oknum ini mampu bertanggungjawab, berdasarkan telaah dalam putusan dan wawancara kepada salah satu narasumber yang berada di dalam satu instansi dengan oknum tersebut unsur ini telah terpenuhi.

4.Tiada alasan pemaaf

Dengan melihat pertimbangan hakim di Pengadilan Negeri Lubuk Linggau bahwa oknum ini telah memenuhi unsur yang ada 
dalam Pasal 69 ayat (1) UndangUndang tentang Sistem

Pendidikan Nasional, perbuatan yang dilakukan merupakan perbuatan pidana yang tidak menghapuskan unsur kesalahannya, jadi sangat wajar untuk dijatuhi pidana sehingga unsur tiada alasan pemaaf ini telah terpenuhi.

Dalam putusan Pengadilan Negeri Lubuk Linggau penulis menyayangkan mengapa wakil rakyat di daerah hanya diputus dengan pidana percobaan sedangkan perbuatannya menggunakan ijazah palsu merupakan perbuatan yang sama saja membohongi rakyat, hal tersebut tidak mencerminkan profesinya sebagai wakil rakyat di daerah yaitu memperjuangkan peningkatan kesejahteraan rakyat, menyerap dan menghimpun aspirasi rakyat, menampung dan menindaklanjuti aspirasi serta memberikan pertanggungjawaban secara moral dan politis kepada rakyat di wilayah pemilihannya.
Memang tidak semua rakyat Indonesia pendidikannya merata, tidak semua orang sukses didasarkan pada pendidikan yang dilaluinya, namun ijazah merupakan suatu tanda yang dasar namun memiliki dampak yang bersar terutama untuk memperoleh pekerjaan.

Padahal berdasarkan pertimbangan hakim, oknum ini telah memenuhi unsur-unsur yang ada dalam Pasal 69 ayat (1) undang-undang tentang sistem pendidikan nasional, juga berdasarkan keterangan para saksi yang menyatakan bahwa ijazah Paket B dan Ijazah Paket C yang dipakai oknum tersebut dalam pencalonannya berdasarkan hasil pemeriksaan kriminalistik yang dibandingkan dengan ijazah asli milik orang lain yang dikeluarkan dinas pendidikan yang bersangkutan, menyatakan ijazah tersebut terbukti palsu dan oknum tersebut sengaja menggunakan ijazah tersebut agar supaya lolos melaju ke kursi legislatif. 
Penulis mempertanyakan mengenai syarat-syarat penjatuhan pidana percobaan, menurut hakim yang penulis wawancarai bahwa syarat-syarat penjatuhan pidana percobaan adalah harus mampu untuk tidak melakukan perbuatan pidana selama masa percobaan, apabila melakukan perbuatan pidana maka harus langsung dijatuhi pidana penjara dan segera dieksekusi. Selanjutnya dengan melihat tingkah laku terdakwa apakah ketika dijatuhkan pidana percobaan terdakwa bisa atau tidak untuk dibina menjadi orang yang lebih baik lagi, di persidangan akan terlihat dan hakim dalam memutus pidana percobaan ini pun memperhatikan hal-hal yang berkaitan dengan itu.

Dengan menelaah pendapat narasumber mengenai syarat-syarat penjatuhan pidana percobaan penulis tidak setuju apabila ada seorang wakil rakyat di daerah yang dengan sengaja menggunakan ijazah palsu dikenakan pidana percobaan, mengapa? Karena menurut penulis pemalsuan ijazah apalagi sampai menggunakan ijazah palsu untuk kepentingan pribadi yang menyangkut banyak orang, ini merupakan suatu pembohongan masyarakat, sangat disayangkan juga apabila penjatuhannya hanya pidana percobaan maka kasus mengenai semacam ini akan terus menerus menjamur dan berlangsung terus menerus, tidak berhenti bahkan akan semakin banyak kasus-kasus seperti ini terjadi. Tidak hanya dalam kasus ini yang penulis jadikan contoh kasus, ada pula kasus serupa seorang wakil ketua Dewan Perwakilan Rakyat Daerah yang menggunakan ijazah palsu, dalam Putusan Pengadilan Negeri Pekalongan dikenakan pidana penjara selama empat bulan namun setelah melakukan berbagai upaya hukum akhirnya dikenakan pidana percobaan dengan syarat khusus. Dari sini akan terlihat bahwa dengan ringannya sanksi pidana yang dijatuhkan kepada para terdakwa pengguna ijazah palsu ini 
menyebabkan tidak adanya efek jera bagi orang-orang yang tidak berpendidikan untuk menjadi calon anggota legislatif dengan memakai ijazah palsu.

Lanjutnya Jaksa Penuntut Umum mengajukan banding yang mana Jaksa Penuntut Umum menyayangkan pidana yang dijatuhkan karena terlalu ringan bagi seorang wakil rakyat daerah. Begitu pula dengan terdakwa dan kuasa hukumnya, beliau mengajukan banding karena merasa tidak adanya keadilan bahwa ada unsur kekeliruan dalam putusan tersbut dan terdakwa juga mempermasalahkan mengenai sakisaksi yang dihadirkan bukan merupakan saksi fakta sebagaimana yang tercantum dalam Pasal 1 angka (26) Kitab Undang-Undang Hukum Acara Pidana, melainkan saksi-saksi yang penuh dengan kepentingan politik. Putusan hakim Pengadilan Tinggi Palembang tersebut tetap mengikuti pertimbangan hakim di Pengadilan Negeri Lubuk linggau yaitu terdakwa terbukti bersalah dengan sengaja menggunakan ijazah yang terbukti palsu yang memenuhi unsur Pasal 69 ayat (1) undangundang sistem pendidikan nasional namun diperbaiki dengan menjatuhkan pidana penjara 1 (satu) tahun kepada terpidana dan pidana denda sebesar Rp 100.000.000,00 (seratus juta rupiah).

Penulis menyoroti mengenai memori banding keduanya, jelas penulis setuju megenai banding yang dilayangkan Jaksa Penuntut Umum bahwa hukuman pidana percobaan dinilai sangat ringan, walaupun penjatuhan sanksi selama satu hari di tahan saja sudah menganggu psikis dan mental terpidana apalagi bagi mereka wakil rakyat ini, namun dengan melihat ketidakadilan disini maka penulis setuju mengenai banding Jaksa Penuntut Umum terhadap putusan Pengadilan Negeri Lubuk Linggau. Selanjutnya penulis menyoroti salah satu memori banding dari terdakwa yang 
menyatakan saksi yang dihadirkan bukan saksi fakta melainkan saksi yang memiliki kepentingan politik. Berdasarkan Putusan MK 65/PUUVIII/2010 makna mengenai saksi itu diperluas, bahwa saksi itu merupakan setiap orang yang punya pengetahuan yang terkait langsung terjadinya tindak pidana wajib didengar sebagai saksi, salah satunya adalah testimonium de auditu yaitu kesaksian atau keterangan karena mendengar dari orang lain. Jadi, penulis setuju dengan putusan Pengadilan Tinggi dengan menolak banding dari terdakwa dan hanya memperbaiki lamanya penjatuhan pidana penjara kepada terdakwa, namun ada hal yang membuat penulis masih tidak setuju dengan penjatuhan pidananya, yaitu penulis menilai penjatuhan pidana selama 1 (satu) tahun masih ringan karena ijazah palsu yang digunakan oleh oknum anggota Dewan Perwakilan Rakyat Daerah tersebut adalah ijazah Paket B dan ijazah Paket C.Terlebih lagi, dalam identitas dirinya beliau merupakan Sarjana Ekonomi, jelas dari awal dalam melanjutkan jenjang pendidikannya ke perguruan tinggi sampai menjadi anggota legislatif oknum ini sudah menggunakan ijazah palsu. Hal ini penulis soroti untuk penjatuhan pidana yang lebih berat yaitu diatas 1 (satu) tahun agar supaya timbul efek jera baik bagi si oknum maupun bagi orang-orang yang berpotensi melakukan perbuatan yang serupa. Kalau seperti ini tidak akan ada efek jera bagi para calon pengguna ijazah palsu ini atau yang menggunakan ijazah palsu.

Menurut Bapak Abdul Ficar, orang yang menggunakan ijazah itu lebih karena terpaksa dan bukan sesuatu kejahatan yang besar, mungkin kalau dia tidak masuk menjadi anggota Dewan Perwakilan Rakyat Daerah dia tidak mungkin menggunakan ijazah palsu tersebut kalau tidak terpaksa. Jadi, jera atau tidak jeranya orang akan tergantung pada kebutuhannya kalau dia tidak masuk menjadi anggota legislatif 
dia tidak membutuhkan ijazah. Orang yang memalsukan ijazah adalah orang yang tidak sekolah dan membutuhkan, jadi tidak bisa pertanyaan jera atau tidak jera. Bisa jadi kalau oknum ini butuh dia akan mengulangi lagi dan tidak jera akan perbuatannya, kasus ini karena ada yang melaporkan ada anggota Dewan Perwakilan Rakyat Daerah yang menggunakan ijazah palsu makanya dilanjutkan ke persidangan.

Penulis setuju dengan pendapat baliau bahwa seseorang jika tidak karena terpaksa tidak mungkin menggunakan ijazah, terlebih ijazah palsu, juga karena pendidikan di Indonesia masih belum merata kebanyakan orang yang mencari pekerjaan dengan peluang untuk menjadi wakil rakyat memanfaatkan jasa pembuatan ijazah. namun, alangkah lebih baiknya apabila penjatuhan pidana dikenakan diatas 1 (satu) tahun agar kejadian seperti kasus penggunaan ijazah palsu berkurang bahkan tidak ada lagi. Sekalipun hakim yang memutus perkara tersebut dalam memeriksa, mengadili dan memutus perkara dalam menjatuhkan sanksi pidana melihat fakta persidangan apakah ada hal-hal yg meringankan atau tidak. hakim juga menjatuhkan pidana melihat dari semua sisi/aspek yaitu, sisi filosofis, sisi yuridis dan sosiologis sosiologis. Jadi tidak hanya sisi yuridis saja, hakim lihat dari fakta persidangan bagaimana dampak ke masyarakat. Sebenarnya penjatuhan pidana tidak semata-mata untuk efek jera saja harus benar-benar apakah terdakwa mampu atau tidak dikembalikan ke masyarakat.

Jika dikaitkan dengan teori pemidanaan yaitu teori gabungan, pemidanaan semata-mata untuk reformasi yaitu memperbaiki atau merehabilitasi terdakwa menjadi orang yang baik dan berguna bagi masyarakat. Mengasingkan pelangar dari masyarakat agar supaya menciptakan lingkungan yang aman. Upaya untuk pembalasan, ini merupakan akibat 
dari perbuatan yang telah dilakukan oleh si terdakwa dan terakhir adalah untuk pencegahan, supaya tidak ada orang yang berpotensi untuk melakukan perbuatan pidana. Berdasarkan teori pemidanaan ini penulis menilai bahwa hakim dalam menjatuhkan pidana telah sesuai dan mempertimbangkan secara matang sesuai dengan pendapat Ibu Hakim Tuty Haryati, harus melihat dari segala aspek baik dari diri si terdakwa maupun bagi masyarakat banyak.

Selanjutnya, keduanya baik Jaksa Penuntut Umum dan terdakwa sama-sama mengajukan kasasi. Jaksa Penuntut Umum masih menganggap penjatuhan pidana kepada terdakwa masih terlalu ringan dan memohon untuk menjatuhkan pidana sesuai dengan tuntutan awal yaitu 2 tahun 6 bulan, sedangkan terdakwa, ia mengajukan kasasi karena menganggap hakim Pengadilan Tinggi hanya mengambil dan membenarkan pertimbangan dari Pengadilan Tinggi dan tidak memberi pertimbangan sendiri secara rinci dengan menggunakan fakta hukum yang terungkap dalam persidangan yaitu mengenai ijazah yang bersangkutan dimana terdakwa mengatakan ijazah asli tidak disita, menyangkal fotokopi ijazah Paket $\mathrm{C}$ bukan merupakan produk fotokopi dari dokumen pembanding dan masih membahas tentang saksi.

Dalam Undang-Undang

Kekuasaan Kehakiman tegas dikatakan bahwa pengajuan kasasi itu terkait mengenai masalah salah menerapkan hukum, pengadilan tidak berwenang dan lain-lain. Jadi kedua permohonan kasasi tersebut ditolak oleh Hakim Mahkamah Agung. Menurut penulis memang hakim Mahkamah Agung tidak berwenang untuk menjatuhkan lamanya pidana/memperbaiki lamanya penjatuhan pidana juga tidak berwenang untuk menelaah fakta-fakta persidangan sebagaimana keberatan yang dilayangkan terdakwa jadi menurut penulis, penulis setuju dengan 
putusan Mahkamah Agung dengan menolak kedua kasasi yang bersangkutan, karena hakim Mahkamah Agung merupakan Judex Juris bukan Judex Facti. Sehingga, terdakwa dijatuhi pidana penjara selama 1 (satu) tahun dan denda Rp 100.000.000,00 (seratus juta rupiah) dimana mengikuti putusan Pengadilan Tinggi Palembang.

Dari rincian analisis tersebut mulai dari Pengadilan Negeri, Pengadilan Tinggi dan sampai pada Mahkamah Agung, terdakwa sebenarnya telah memenuhi unsur pertanggungjawaban pidana, apalagi terdakwa merupakan wakil rakyat daerah yang dengan sengaja menggunakan ijazah palsu. Berdasarkan narasumber yang penulis wawancarai, oknum anggota Dewan Perwakilan Rakyat Daerah ini telah melaksanakan hukumannya sehingga pertanggungjawaban pidana jika dilihat dari putusan, dengan merujuk kepada dipertimbangan hukumnya artinya berdasarkan pertimbangan hukum ini pengadilan sudah mempertimbangan segala bukti sehingga dia bisa dimintai pertanggungjawaban pidana. Jadi, jika dikaitkan dengan putusan dan teori maka hakim sudah sesuai memutuskan.

\section{III.PENUTUP}

\section{A. Kesimpulan}

Dari hasil analisis yang telah penulis tuangkan yang telah dikaitkan dengan teori-teori yang ada maka kesimpulan yang penulis dapat adalah: seseorang dapat dimintai pertanggungjawaban apabila telah memenuhi unsur:

1. Telah dilakukannya tindak pidana

2. Adanya kesalahan

3. Orang yang mampu bertanggungjawab

4. Tiada alasan pemaaf

Pertanggungjawaban pidana bagi oknum pengguna ijazah palsu oleh anggota Dewan 
Perwakilan Rakyat Daerah ini, harus memenuhi :

1. Telah dilakukannya tindak pidana.

Dalam kasus ini bahwa telah terjadi tindak pidana pemalsuan ijazah atau lebih konkritnya dengan sengaja menggunakan ijazah palsu yang digunakan dalam pemilihan umum legilatif di daerah. Jelas unsur ini telah terpenuhi.

2. Adanya kesalahan (dollus atau culpa).

Dalam kasus ini si pengguna ijazah palsu di dalam putusannya telah memenuhi unsur dengan sengaja menggunakan ijazah palsu, berarti dalam melakukan tindak pidananya dia dengan sengaja menggunakan ijazah palsu agar supaya lolos menjadi anggota legislatif, dan lagi dai membayar orang sebesar Rp. 10.000.000,00 (sepuluh juta rupiah) agar ijazah Paket B dan Paket C berada di tanganya. Sehingga menurut penulis adanya unsur kesalahan dalam kasus ini telah terpenuhi.

3. Kemampuan

bertanggungjawab

Dalam kasus ini bahwa si terdakwa adalah orang yang sehat jiwa dan raganya. Jika dilihat dari putusan bahwa si terdakwa ini adalah oknum anggota Dewan Perwakilan Rakyat Daerah yang mana, pada saaat pencalonan dirinya sebagai anggota legislatif yang salah satu syaratnya adalah sehat jasmani dan rohani. Oknum ini dengan sengaja menggunakan ijazah palsu dalam pemilihan legislatif pasti menyadari apa akibat yang ditimbulkan dari perbuatan yang dilakukannya. Jika dilihat dari umurnya pun oknum ini merupakan orang 
yang sehat jadi menurut

penulis bisa dimintai

pertanggungjawaban.

Dia memiliki kehendak untuk menggunakan ijazah itu dan dia menginsyafi akan akibat dari perbuatannya itu namun selama masih atau belum ada yang memperkarakan oknum ini masih dapat melaksanakan tugasnya sebagai anggota DPRD.

Jika dilihat apakah oknum ini mampu

bertanggungjawab,

berdasarkan telaah dalam putusan dan wawancara kepada salah satu narasumber yang berada di dalam satu instansi dengan oknum tersebut unsur ini telah terpenuhi.

4. Tiada alasan pemaaf.

Dengan melihat pertimbangan hakim di Pengadilan Negeri Lubuk linggau bahwa oknum ini telah memenuhi unsur yang ada dalam Pasal 69 ayat (1) Undang-Undang tentang Sistem Pendidikan Nasional, perbuatan yang dilakukan merupakan perbuatan pidana yang tidak menghapuskan unsur kesalahannya, jadi sangat wajar untuk dijatuhi pidana sehingga unsur tiada alasan pemaaf ini telah terpenuhi.

Dari kasus yang penulis angkat mengenai penggunaan ijazah palsu, bahwa oknum anggota Dewan Perwakilan Rakyat Daerah ini telah memenuhi unsur pertanggungjawaban pidana, apalagi terdakwa merupakan wakil rakyat yang dengan sengaja menggunakan ijazah palsu. Juga, oknum anggota Dewan Perwakilan Rakyat Daerah ini telah melaksanakan hukumannya sehingga pertanggungjawaban pidana jika dilihat dari putusan, dengan merujuk kepada dipertimbangan hukumnya artinya berdasarkan pertimbangan hukum ini pengadilan sudah mempertimbangan segala bukti dan dia bisa dimintai 
pertanggungjawaban pidana. Jadi, jika dikaitkan dengan putusan dan teori maka hakim sudah sesuai memutuskan.

\section{B. Saran}

Untuk mencegah dan menghindari kasus serupa mengenai ijazah palsu maka penulis memberikan saran kepada beberapa pihak agar tidak ada lagi hal semacam ini:

1. Bagi pemerintah untuk memperketat lagi sistem pemilihan umum legislatif baik untuk di pusat maupun untuk di daerah, karena penggunaan ijazah palsu ini walaupun sesuatu yang dasar namun dampaknya besar baik bagi pribadi si pengguna ijazah palsu maupun bagi masyarakat luas. Serta melakukan sosialisasi agar supaya tidak ada indikasi penggunaan ijazah palsu dalam pemenuhan syarat sebagai anggota legislatif.

2. Bagi hakim, menurut penulis agar supaya tidak ada lagi kasus-kasus ijazah palsu baik dari si pemalsu ijazah sampai si pemakai ijazah palsu perlu adanya penjatuhan pidana yang berat bagi setiap pelaku. Walaupun hakim kita dalam menjatuhkan pidana sudah berdasarkan teori pemidanaan yaitu memperbaiki diri si pelaku agar menjadi orang yang lebih baik, mengasingkan si pelaku dari masyarakat, penjatuhan pidana sebagai pembalasan dan pencegahan. Namun, alangkah lebih baik lagi penjatuhan sanksi berat bagi pengguna ijazah palsu khususnya bagi mereka wakilwakil rakyat.

3. Bagi para calon legislatif agar jujur dalam pencalonan diri sebagai wakil rakyat, karena profesinya yang mulia sangat disayangkan apabila tidak dimaksimalkan dalam pemenuhan syarat-syarat sebagai anggota legislatif.

\section{DAFTAR PUSTAKA}

\section{A. Buku}

Chazawi, Adami. Kejahatan Mengenai Pemalsuan. Jakarta: PT Raja Grafindo Persada, 2002. 
Volume 17, No. 1, Juni 2019

Lamintang. Dasar-Dasar Hukum

Pidana Indonesia. Bandung: Sinar

Baru, 1984.

Nawawi, Muladi Barda. Teori-Teori

dan Kebijakan Pidana.

Cetakan ke-2. Bandung:

Penerbit Alumni, 1992.

Viswandro, dkk. Mengenal Profesi

Penegak Hukum. Cetakan

ke-1. Yogyakarta: penerbit

Medpress Digital, 2015.

Prodjodikoro, Wirjono. Asas-Asas

Hukum Pidana di

Indonesia. Edisi kedua.

Bandung: Eresco, 1986.

\section{B. Artikel Jurnal Online}

Karinda, Angel Michelle Karinda.

"Kajian Yuridis Terhadap

Tentang Pemalsuan

Pemalsuan Ijazah Menurut

Pasal 263 dan 264 KUHP”,

Lex Crimen Vol. V Tahun

2016. 